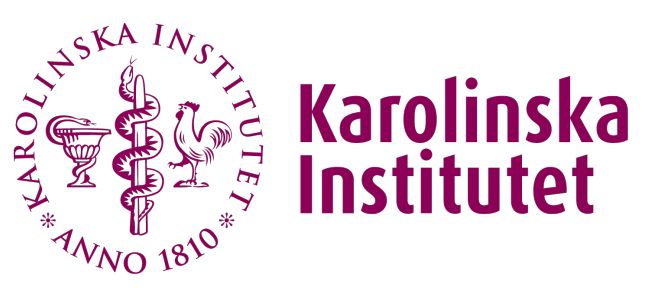

Karolinska Institutet

http://openarchive.ki.se

This is a Peer Reviewed Manuscript version of the following article, accepted for publication in Human Immunology.

\title{
Frequency analysis of HLA class I alleles in Iranian patients with progressive and non-progressive chronic lymphocytic leukemia
}

Hojjat-Farsangi, Mohammad; Razavi, Seyed Mohsen; Sharifian, Ramazan Ali; Shokri, Fazel

Hum Immunol. 2014 Feb;75(2):170-5.

http://doi.org/10.1016/j.humimm.2013.11.003

http://hdl.handle.net/10616/41860

If not otherwise stated by the Publisher's Terms and conditions, the manuscript is deposited under the terms of the Creative Commons Attribution-NonCommercial-NoDerivatives License (http://creativecommons.org/licenses/by-nc-nd/4.0/), which permits non-commercial re-use, distribution, and reproduction in any medium, provided the original work is properly cited, and is not altered, transformed, or built upon in any way. 


\section{(19) \\ Karolinska Institutet}

This is an author produced version of a paper published in Human Immunology. This paper has been peer-reviewed but does not include the final publisher proof-corrections or journal pagination.

Hum Immunol. 2013 Nov 21. pii: S01988859(13)00566-1.

Frequency analysis of HLA class I alleles in Iranian patients with progressive and non-progressive chronic lymphocytic leukemia

Hojjat-Farsangi, Mohammad; Razavi, Seyed Mohsen; Sharifian, Ramazan Ali; Shokri, Fazel

URL: http://dx.doi.org/10.1016/j.humimm.2013.11.003

Access to the published version may require subscription. Published with permission from: Elsevier 


\title{
Frequency analysis of HLA class I alleles in Iranian patients with progressive and non-progressive chronic lymphocytic leukemia
}

\author{
Hojjat-Farsangi $\mathrm{M}^{1,2,3}$, Razavi $\mathrm{SM}^{4}$, Sharifian RA ${ }^{5}$, Shokri $\mathrm{F}^{2,6, *}$
}

\footnotetext{
${ }^{1}$ Department of Oncology-Pathology, Immune and Gene Therapy Lab, Cancer Center Karolinska (CCK), Karolinska University Hospital Solna and Karolinska Institute, Stockholm, Sweden

${ }^{2}$ Department of Immunology, School of Public Health, Tehran University of Medical Sciences, Tehran, Iran

${ }^{3}$ Department of Immunology, School of Medicine, Bushehr University of Medical Sciences, Bushehr, Iran

${ }^{4}$ Clinic of Hematology and Oncology, Firozgar Hospital, Faculty of Medicine, Iran University of Medical Sciences, Tehran, Iran

${ }^{5}$ Clinic of Hematology and Oncology, Vali-Asr Hospital, Faculty of Medicine, Tehran University of Medical Sciences, Tehran, Iran

${ }^{6}$ Monoclonal Antibody Research Center, Avicenna Research Institute, ACECR, Tehran, Iran
}

* Corresponding author: Fazel Shokri, Ph.D; Professor, Department of Immunology, School of Public Health, Tehran University of Medical Sciences, Tehran, Iran

Tel.: +98 2188953021 ; Fax: +98 2188954913.

E-mail: fshokri@sina.tums.ac.ir

Key words: HLA-I, chronic lymphocytic leukemia, immunoglobulin heavy chain variable region (IGHV), disease progression

Running title: Frequency of HLA class I alleles in Iranian CLL patients 


\begin{abstract}
Chronic lymphocytic leukemia (CLL) is a malignant disorder of B cell origin, with low incidence in Asian populations. In this study we investigated the HLA-class I A and B allele frequencies in 87 Iranian CLL patients and 64 healthy controls using sequence specific primer-polymerase chain reaction (SSP-PCR) technique. Our results showed increased frequencies of HLA-A11:01 $(\mathrm{p}=0.02)$ and HLA-B35:01 $(\mathrm{p}=0.002)$ alleles and HLA-A11:01/B35:01 haplotype $(\mathrm{p}=0.036)$ and decreased frequencies of HLA-A01:01 ( $p=0.02)$, HLA-A26:01 ( $p=0.03)$, HLA-B65:01 ( $p=0.03)$ and HLA-B53:01 $(\mathrm{p}<0.00001)$ alleles in CLL patients compared to the control group. Classification of the patients into non-progressive and progressive groups did not reveal significant differences for the frequency of any of the HLA-A and B alleles or haplotypes between these two subtypes. Comparison between patients with immunoglobulin heavy chain variable region genes (IGHV) mutated $(n=56)$ and unmutated $(n=31)$ subtypes showed a significant increase in HLA-A32:01 $(\mathrm{p}=0.05)$ and HLA-A33:01 $(\mathrm{p}=0.05)$ alleles in IGHV unmutated patients compared to IGHV mutated patients. Similarly, a higher frequency of HLAB52:01 ( $\mathrm{p}=0.037)$ alleles was observed in CD38+ compared with CD38- patients. Our results obtained from an Iranian population indicate that CLL is associated with distinct HLA class I alleles and haplotypes some of which are linked to disease prognostic factors.
\end{abstract}




\section{Introduction}

Chronic lymphocytic leukemia (CLL), a hematologic malignancy of $\mathrm{CD}^{+} \mathrm{CD} 19^{+} \mathrm{CD} 23^{+} \mathrm{B}$-cells [1], is considered as the most abundant leukemia in the West [2, 3]. Compared to the Western populations, its frequency is low in Asia and Iran [4-6]. Clinically, the disease could either be progressive or non-progressive with overall survival time ranging from less than 5 years to more than 30 years. Despite recent identification of several prognostic factors $[7,8]$ the etiology of CLL remains obscure. Recent investigations on the immunoglobulin heavy chain variable region (IGHV) genes stereotypes of the leukemic B cells suggest involvement of antigen selection in initiation or progression of CLL $[9,10]$. Sequencing of the expressed IGHV genes has shown that patients with CLL can be classified into IGHV mutated or unmutated subtypes [11]. Patients having leukemic cells with unmutated IGHV genes usually display a more aggressive disease compared to those with mutated IGHV genes $[12,13]$.

HLA genes are the most polymorphic genes which are involved in antigen presentation to $\mathrm{T}$ lymphocytes. Expression of certain HLA class I or II alleles has been shown to be associated with a variety of infections and autoimmune or malignant disorders [14-16].

Taking into consideration the genetic diversity and variability of HLA alleles in different ethnic populations, different HLA class I and II alleles might be associated to a given disease in different populations.

Association of certain HLA class I [17] or HLA class II [14, 18] alleles with the clinical course of the disease has also been reported in different malignancies.

Apart of a few studies $[4,16,19-26]$ in which the frequency of HLA alleles has been determined in CLL patients from some ethnic populations, association of HLA alleles and CLL prognosis has 
not been well studied, especially in the Asian CLL patients. In a prior study we reported the frequency of some HLA class I A, B and C antigens in a limited number of CLL patients using the serological microlymphocytotoxicity technique [4]. Later, we reported the HLA class II allele frequencies in a large number of Iranian CLL patients and their correlation to disease progression and IGHV mutation [14]. In the current study, we investigated the frequency of HLA-class I A and B alleles and haplotypes by SSP-PCR technique in the same set of patients. Contrary to our previous serologic HLA class I study, the patients were classified into different molecular and clinical subtypes (progressive and non-progressive, IGHV mutated and unmutated, as well as CD38+ and CD38- subtypes) which allowed analysis of the association of HLA alleles and haplotypes with disease progression. 


\section{Materials and Methods}

\section{Patients and controls}

In the present study, from 87 Iranian CLL patients, $20 \mathrm{ml}$ of heparinized peripheral blood was collected. All patients attended the Hematology and Oncology Clinics of Vail-Asr and Firozgar Hospitals, affiliated to Tehran University of Medical Sciences. Consent letter was taken from all patients and the study was approved by the Ethical Committee of Tehran University of Medical Sciences. CLL diagnosis and classification of our patients have been described previously [14]. Patients were considered to have progressive disease if the following criteria were met: progression during the preceding 3 months in disease-related anemia (hemoglobin <100 g/l), thrombocytopenia $(<100 \times 109 / 1)$ and/or an increase in spleen/liver/lymph node size and/or more than a 2-fold increase in the blood lymphocyte count [14, 27, 28]. HLA typing results were compared with those obtained from 64 Iranian healthy blood donors. Since the age of the subjects does not seem to influence HLA frequency profile, the control group was not age matched with CLL patients and was selected from adult volunteers (23-45 years old; mean age: 34 years).

\section{Typing of HLA-A and HLA-B alleles}

HLA class I alleles of patients and controls were defined using low-resolution kits supplied by Qiagen Vertriebs GmbH (Vienna, Austria), based on the manufacturer's instructions.

To define the HLA-A and -B alleles in patients and controls, genomic DNA of each sample was amplified by 24 and 48 cycles of PCR reactions for HLA-A and HLA-B specificities, respectively. Allele frequencies in CLL patients and controls were calculated by direct counting. Two-locus haplotype (HLA-A/B) frequencies in patients and healthy controls were estimated by maximum-likelihood method according to the expectation-maximization algorithm using Arlequin 2.0 [29]. 


\section{Analysis of IGHV genes mutations}

Total cellular RNA was isolated from PBMCs of CLL patients using RNA-Bee (BioSite, Taby, Sweden) based on the guanidine thiocyanate phenol chloroform extraction method. First strand cDNA was synthesized from 1-3 ug of total RNA as described previously [14]. To determine the IGHV family gene expression by polymerase chain reaction (PCR), serial dilutions of DNA and cDNA (1:10 to 1:2000) were prepared and PCR amplification was performed using IGHV family-specific degenerative primers. PCR reactions were performed as described [14]. Finally clonal PCR products were purified by excision using the QIAquick gel extraction kit (Qiagen, Hilden, Germany) and were cloned into pGEM-T easy vector (Promega, Southampton, United Kingdom). Sequencing was performed from both directions using the BigDye Terminator Cycle Sequencing Reaction Kit (Applied Biosystems, Foster City, CA, USA), and T7 and SP6 primers. For each sample IGHV gene was identified by matching to the closest known human germline gene using the ImMuno-Gene Tics (IMGT) Database (http://imgt.cines.fr) and the IgBLast search (http://www.ncbi.nlm.nih.gov/igblast/). Classification of patients into mutated $(\mathrm{n}=56)$ and unmutated $(\mathrm{n}=31)$ subtypes was based on more than $98 \%$ homology in nucleotide sequence of IGHV genes of the leukemic cells [30].

\section{Statistical analysis}

The association of CLL with HLA-I alleles was analyzed by comparing HLA-A and -B alleles frequencies in CLL patients with 64 healthy Iranian controls. Maximum likelihood method was used to evaluate the haplotype frequencies for the two-loci. Chi-Square test for $2 \times 2$ tables after Yates correction was used to define the differences between allele frequencies in patients and

controls and patients subgroups, using Epi-Info and SPSS statistical packages (SPSS Inc., 
Chicago, IL). The odds ratios (OR) with $95 \%$ confidence intervals (CI) were calculated and pvalues lower than 0.05 were considered to be significant. The Mann-Whitney U test was also used to compare the time to first treatment (TTFT), progression free survival (PFS) and overall survival (OS) between different CLL subtypes. 


\section{Results}

\section{HLA-A and B frequencies in CLL patients and controls}

In the current study, 87 CLL patients and 64 healthy donors were included. The frequencies of HLA-A and HLA-B alleles in all patients and controls are presented in Tables 1 and 2. Our results showed that HLA-A02 and HLA-A24 have the highest frequency among HLA-A alleles in CLL patients (25.3\% and 16.7\%) and controls (15.6\% and 16.4\%), respectively. HLA-A03 and HLA-A11 are the next alleles with higher frequencies in CLL patients. Comparing the frequency of HLA-A alleles between patients and controls shows substantially higher frequencies of HLAA11 $(\mathrm{OR}=3.38, \mathrm{p}=0.02)$ and HLA-A02 $(\mathrm{OR}=1.83, \mathrm{p}=0.059)$ and lower frequencies of HLA-A01 $(\mathrm{OR}=0.34, \mathrm{p}=0.02)$ and HLA-A26 $(\mathrm{OR}=0.32,0.03)$ in CLL patients (Table 1). The most abundant HLA-B allele in patients was HLA-B35. This alleles was expressed in CLL patients at a significantly higher frequency compared to controls ( $19 \%$ vs. $6.3 \%, \mathrm{OR}=3.51, \mathrm{p}=0.002)$. On the other hand HLA-B53 allele was among the least expressed HLA-B alleles in CLL patients, but the most frequent allele expressed in the control subjects $(\mathrm{OR}=0.04, \mathrm{p}=0.00001)$. HLA-B65:01 was also observed at significantly lower frequency in patients compared to controls $(\mathrm{OR}=0.17$, $\mathrm{p}=0.03)($ Table 2).

\section{Frequencies of HLA-I alleles in CLL subtypes}

The association of HLA-A and HLA-B alleles to disease progression was analyzed in CLL patients. The frequencies of HLA-A02:01, HLA-A24:01 and HLA-A03:0 alleles were lower in progressive CLL patients, but the differences were not statistically significant. Comparison of HLA-A allele frequencies between IGHV mutated and unmutated CLL patients showed a higher frequency of HLA-A32:01 (6.5\% vs. 0.9\%, $\mathrm{OR}=0.13, \mathrm{p}=0.05)$ and HLA-A33:01 (6.5\% vs. 0.9\%, $\mathrm{OR}=0.13, \mathrm{p}=0.05)$ in IGHV unmutated compared to IGHV mutated patients. Comparison of 
$\mathrm{CD}^{+} 8^{+}$and $\mathrm{CD}^{-} 8^{-}$groups of patients demonstrated a positive association of HLA-A30:01 and HLA-A68:01 alleles with $\mathrm{CD} 38$ expression $(\mathrm{OR}=3.5, \mathrm{p}=0.09$ and $\mathrm{OR}=7.9, \mathrm{p}=0.06$ respectively), but the differences were not statistically significant.

The frequencies of HLA-B alleles were analysed in CLL subtypes. Significant differences were observed neither between non-progressive and progressive nor IGHV mutated and unmutated CLL subgroups. A significantly higher frequency of HLA-B52:01 was observed in CD38 ${ }^{+}$ compared to $\mathrm{CD} 38^{-}$CLL patients $(10.4 \%$ vs. $2.4 \%, \mathrm{OR}=4.77, \mathrm{p}=0.037)$. The most frequent homozygote alleles of HLA-A and HLA-B were HLA-A24:01 (8.5\%) and HLA-B35:01 (6.9\%) in CLL patients (Table 3). None of the controls expressed HLA-B35:01 homozygote allele, but the difference between CLL patients and healthy controls was not statistically significant.

\section{HLA-A and -B haplotypes frequency}

The frequencies of two loci haplotypes in CLL patients and healthy controls are shown in Table 4. HLA-A02:01/B35:01, HLA-A24:01/B35:01, HLA-A03:01/B35:01 and HLA-A11:01/B35:01

were the most frequent haplotypes in patients, however, only the frequency of the latter haplotype was significantly higher in the patients compared to the control group $(\mathrm{p}=0.036)$. None of the haplotypes was found to be associated to a particular subtype of CLL patients.

\section{Association between TTFT, PFS and OS with HLA I alleles}

Comparison of TTFT, PFS and OS in our CLL patients showed no significant correlations between these parameters and frequency of certain HLA-A or -B alleles. 


\section{Discussion}

Association between HLA antigens and disease initiation or progression has been investigated in a limited number of hematological malignancies, including CLL [14]. The frequency of HLA class I alleles in CLL has been reported in a few ethnic populations (Table 5). Patients with CLL are classified into IGHV mutated and unmutated subtypes based on the mutational status of the IGHV genes of the leukemic B-cells [11]. These two different subtypes of patients have different molecular and clinical features, in terms of CD38 and ZAP-70 expression and disease progression [31, 32]. CLL patients with mutated IGHV genes tend to express lower levels of CD38 and ZAP-70 molecules with a milder disease, as compared to patients with unmutated $I G H V$ genes $[12,13,30]$.

In the current study, we demonstrated the HLA class I A and B alleles frequencies in a group of Iranian CLL patients and healthy controls trying to identify the disease predisposing or protective alleles and haplotypes in our patients. Of the HLA-A alleles, HLA-A11:01 was represented at a higher frequency in our patients compared with controls $(\mathrm{OR}=3.38, \mathrm{p}=0.02)$, while the frequencies of HLA-A01:01 and HLA-A26:01 alleles were significantly higher in the control group $(\mathrm{OR}=0.34$ and $0.32, \mathrm{p}=0.02$ and 0.03 , respectively). Our results are not compatible with those of Linet et al who reported no difference in the frequencies of HLA-A01 and HLA-A26 alleles between their CLL patients and healthy controls [21], which may partly be due to ethnic differences.

Among the HLA-B alleles we observed a significantly higher frequency of HLA-B35:01 allele in our CLL patients compared to controls $(\mathrm{OR}=3.51, \mathrm{p}=0.002)$, showing a strong association of this

allele with CLL disease. A similar finding was also reported by others [20], though controversial 
results have also been published [16, 21, 22, 25, 33]. An increased frequency of the HLA-B35 allele has also been reported in some other malignancies and autoimmune diseases from different ethnic populations, including Hodgkin's lymphoma [34], autoimmune thyroiditis [35], autoimmune hepatitis [36] autoimmune arthritis [37], Moyamoya [38], and pemphigus vulgaris [39], suggesting a critical correlation of this allele with hematologic malignancies and other pathologic conditions.

In contrast to higher frequency of HLA-B35:01 in CLL patients, a significantly lower frequency of HLA-B65:01 (OR=0.17, $\mathrm{p}=0.03)$ and particularly HLA-B53:01 ( $\mathrm{OR}=0.04, \mathrm{p}=0.00001)$ alleles was observed in our patients compared to the healthy controls, suggesting a protective role for these alleles. To our knowledge negative association of these two alleles with CLL has not been reported in other ethnic populations, suggesting ethnical influence of HLA association to CLL disease.

The differences observed in allele frequencies between patients and controls might be interpreted to reflect differences between different subgroups of the Iranian population. Ethnically, the Iranian population is derived from the Caucasian ancestral, though it is composed of different ethnic subpopulations, including Turk, Kurd, Arab, Fars, Balooch, Lor and Turkman people [40]. These populations are living in different provinces of Iran. However, Tehran, the capital of Iran, is populated with all these subgroups. Thus, since the samples were collected from patients and personnel of two university hospitals located in Tehran, we assume that it is unlikely that the differences observed in allele frequencies between our patients and controls are associated to population subgroups.

Comparison of the frequency of HLA-A alleles in different subtypes of our CLL patients showed a significantly higher frequency of HLA-A32:01 and HLA-A33:01 alleles in IGHV unmutated compared to mutated patients. 
A higher frequency of HLA-A33 allele has previously been reported in patients with other disorders [41, 42]. Among the HLA-B alleles, HLA-B52:01 allele was expressed at a higher frequency in CLL patients expressing CD38 molecule, compared to CD38- patients $(\mathrm{OR}=4.77$, $\mathrm{p}=0.037$ ). Association between expression of CD38 and/or lack of IGHV mutation with disease progression has been reported in various studies [7, 43, 44]. Accordingly, HLA-A32:01, A33:01 and B52:01 alleles seem to be positively associated to disease progression in our CLL patients. As we reported previously [14], non-progressive and IGHV mutated CLL patients had a higher PFS (44 and 37 months, respectively) compared to progressive and unmutated (13 and 9 month, respectively) CLL patients ( $\mathrm{p}=0.006$ and 0.001 , respectively). Also, IGHV unmutated CLL patients had significantly lower overall survival compared to mutated patients $(98 \%$ vs. $84 \%$, $\mathrm{p}=0.04$ ). Our findings of lack of significant correlations between TTFT, PFS and OS with frequency of expression of none of the HLA-A or $-\mathrm{B}$ alleles in our CLL patients suggest that different prognostic parameters may give different levels of associations with HLA alleles frequency.

The negative association of certain HLA-I antigens such as HLA-B53:01 with CLL implies expansion of a repertoire of tumor-specific CTL clones which enables effective immunomonitoring and control of tumor cells in healthy subjects. The association of some HLA alleles or haplotypes with CLL disease and its progression may also confer a protective role in CLL in which the leukemic cells and/or antigen presenting cells can efficiently present tumor related antigens to autologous T cells, leading to their stimulation. Differential frequency of some HLA class I alleles in different subtypes of our CLL patients is in agreement with this proposition. 
Altogether, our findings together with the signaling effects of HLA-I molecules and effects on tumor cells behavior imply that certain HLA antigens may influence the immune response to leukemic CLL cells, probably through different mechanisms such as presentation of a tumorassociated antigen by leukemic B cells or by professional antigen-presenting cells to autologous $\mathrm{T}$ cells and shaping the repertoire of $\mathrm{T}$ cells as explained. Alternatively, such alleles may be regarded as markers for other pathogenic genes remaining in linkage disequilibrium with these loci.

\section{Acknowledgements}

This study was supported by a grant from the Nanotechnology Network of the Ministry of Health and Medical Education of Iran. 


\section{References}

[1] Dighiero G, Hamblin TJ. Chronic lymphocytic leukaemia. Lancet 2008; 371: 1017-1029.

[2] Byrd JC, Stilgenbauer S, Flinn IW. Chronic lymphocytic leukemia. Hematology Am Soc Hematol Educ Program 2004: 163-183.

[3] Faguet GB. Chronic lymphocytic leukemia: an updated review. J Clin Oncol 1994; 12: 1974-1990.

[4] Moazzeni SM, Amirzargar AA, Shokri F. HLA antigens in Iranian patients with B-cell chronic lymphocytic leukemia. Pathol Oncol Res 1999; 5: 142-145.

[5] Tamura K, Sawada H, Izumi Y, Fukuda T, Utsunomiya A, Ikeda S, et al. Chronic lymphocytic leukemia (CLL) is rare, but the proportion of T-CLL is high in Japan. Eur $\mathbf{J}$ Haematol 2001; 67: 152-157.

[6] Hojjat Farsangi M, Jeddi-Tehrani M, Razavi SM, Sharifian RA, Shamsian Khoramabadi A, Rabbani H, et al. Immunophenotypic characterization of the leukemic B-cells from Iranian patients with chronic lymphocytic leukemia: association between CD38 expression and disease progression. Iran J Immunol 2008; 5: 25-35.

[7] Durig J, Naschar M, Schmucker U, Renzing-Kohler K, Holter T, Huttmann A, et al. CD38 expression is an important prognostic marker in chronic lymphocytic leukaemia. Leukemia 2002; 16: 30-35.

[8] Trojani A, Montillo M, Nichelatti M, Tedeschi A, Colombo C, Veronese S, et al. ZAP-70, $\mathrm{IgVh}$, and cytogenetics for assessing prognosis in chronic lymphocytic leukemia. Cancer Biomark 2010; 6: 1-9.

[9] Forconi F, Potter KN, Wheatley I, Darzentas N, Sozzi E, Stamatopoulos K, et al. The normal IGHV1-69-derived B-cell repertoire contains stereotypic patterns characteristic of unmutated CLL. Blood 2010; 115: 71-77.

[10] Agathangelidis A, Darzentas N, Hadzidimitriou A, Brochet X, Murray F, Yan XJ, et al. Stereotyped B-cell receptors in one-third of chronic lymphocytic leukemia: a molecular classification with implications for targeted therapies. Blood 2012; 119: 4467-4475.

[11] Fais F, Ghiotto F, Hashimoto S, Sellars B, Valetto A, Allen SL, et al. Chronic lymphocytic leukemia B cells express restricted sets of mutated and unmutated antigen receptors. J Clin Invest 1998; 102: 1515-1525.

[12] Hamblin TJ, Davis Z, Gardiner A, Oscier DG, Stevenson FK. Unmutated Ig V(H) genes are associated with a more aggressive form of chronic lymphocytic leukemia. Blood 1999; 94: 1848-1854.

[13] Damle RN, Wasil T, Fais F, Ghiotto F, Valetto A, Allen SL, et al. Ig V gene mutation status and CD38 expression as novel prognostic indicators in chronic lymphocytic leukemia. Blood 1999; 94: 1840-1847.

[14] Hojjat-Farsangi M, Jeddi-Tehrani M, Amirzargar AA, Razavi SM, Sharifian RA, Rabbani $\mathrm{H}$, et al. Human leukocyte antigen class II allele association to disease progression in Iranian patients with chronic lymphocytic leukemia. Hum Immunol 2008; 69: 666-674.

[15] Charron D. HLA, immunogenetics, pharmacogenetics and personalized medicine. Vox Sang 2011; 100: 163-166.

[16] Machulla HK, Muller LP, Schaaf A, Kujat G, Schonermarck U, Langner J. Association of chronic lymphocytic leukemia with specific alleles of the HLA-DR4:DR53:DQ8 haplotype in German patients. Int J Cancer 2001; 92: 203-207. 
[17] Chang CC, Campoli M, Ferrone S. Classical and nonclassical HLA class I antigen and NK Cell-activating ligand changes in malignant cells: current challenges and future directions. Adv Cancer Res 2005; 93: 189-234.

[18] Marsman M, Jordens I, Griekspoor A, Neefjes J. Chaperoning antigen presentation by MHC class II molecules and their role in oncogenesis. Adv Cancer Res 2005; 93: 129158 .

[19] Montes-Ares O, Moya-Quiles MR, Montes-Casado M, Guerra-Perez N, Campillo JA, Gonzalez C, et al. Human leucocyte antigen-C in B chronic lymphocytic leukaemia. Br J Haematol 2006; 135: 517-519.

[20] Cuttner J, Skerrett D, Rosina O, Troy KM, Wallenstein S, Spivack M. Increased incidence of HLA antigen B35 in patients with chronic lymphocytic leukemia. Leuk Res 1994; 18: 565-567.

[21] Linet MS, Bias WB, Dorgan JF, McCaffrey LD, Humphrey RL. HLA antigens in chronic lymphocytic leukemia. Tissue Antigens 1988; 31: 71-78.

[22] Dorak MT, Machulla HK, Hentschel M, Mills KI, Langner J, Burnett AK. Influence of the major histocompatibility complex on age at onset of chronic lymphoid leukaemia. Int J Cancer 1996; 65: 134-139.

[23] Nouri AM, Smith S, Oliver TR, Newland AC, Macey MG. Comparative expression of major histocompatibility complex (MHC) antigens on CD5+ and CD5- B cells in patients with chronic lymphocytic leukaemia (CLL). Eur J Cancer 1998; 34: 1618-1622.

[24] Van Scoy-Mosher MB, Bick M, Capostagno V, Walford RL, Gatti RA. A clinicopathologic analysis of chronic lymphocytic leukemia. Am J Hematol 1981; 10: 918.

[25] Kilpatrick DC, Dewar AE, Stockdill G, Maginnis M, Jordan A, Neill GW, et al. Histocompatibility antigen frequencies in patients with chronic lymphocytic leukaemia: possible identification of a subgroup with relatively benign disease. Scand J Haematol 1984; 33: 391-396.

[26] Dyer PA, Ridway JC, Flanagan NG. HLA-A,B and DR antigens in chronic lymphocytic leukaemia. Dis Markers 1986; 4: 231-237.

[27] Hojjat-Farsangi M, Jeddi-Tehrani M, Razavi SM, Sharifian RA, Mellstedt H, Shokri F, et al. Immunoglobulin heavy chain variable region gene usage and mutational status of the leukemic B cells in Iranian patients with chronic lymphocytic leukemia. Cancer Sci 2009; 100: 2346-2353.

[28] Memarian A, Hojjat-Farsangi M, Asgarian-Omran H, Younesi V, Jeddi-Tehrani M, Sharifian RA, et al. Variation in WNT genes expression in different subtypes of chronic lymphocytic leukemia. Leuk Lymphoma 2009; 50: 2061-2070.

[29] Excoffier L, Laval G, Schneider S. Arlequin (version 3.0): an integrated software package for population genetics data analysis. Evol Bioinform Online 2005; 1: 47-50.

[30] Maloum K, Davi F, Merle-Beral H, Pritsch O, Magnac C, Vuillier F, et al. Expression of unmutated $\mathrm{VH}$ genes is a detrimental prognostic factor in chronic lymphocytic leukemia. Blood 2000; 96: 377-379.

[31] Rosenwald A, Alizadeh AA, Widhopf G, Simon R, Davis RE, Yu X, et al. Relation of gene expression phenotype to immunoglobulin mutation genotype in B cell chronic lymphocytic leukemia. J Exp Med 2001; 194: 1639-1647.

[32] Ferrer A, Ollila J, Tobin G, Nagy B, Thunberg U, Aalto Y, et al. Different gene expression in immunoglobulin-mutated and immunoglobulin-unmutated forms of chronic lymphocytic leukemia. Cancer Genet Cytogenet 2004; 153: 69-72. 
[33] Jones HP, Whittaker JA. Chronic lymphatic leukaemia: an investigation of HLA antigen frequencies and white cell differential counts in patients, relatives and controls. Leuk Res 1991; 15: 543-549.

[34] Greene MH, McKeen EA, Li FP, Blattner WA, Fraumeni JF, Jr. HLA antigens in familial Hodgkin's disease. Int J Cancer 1979; 23: 777-780.

[35] Nyulassy S, Hnilica P, Stefanovic J. The HL-A system and subacute thyroiditis. A preliminary report. Tissue Antigens 1975; 6: 105-106.

[36] Huang HC, Wu JC, Huang YS, Teh-Ia H, Lo JC, Li CP, et al. Genetic distinctions and clinical characteristics of type 1 autoimmune hepatitis in Taiwan. Hepatogastroenterology 2008; 55: 605-608.

[37] Saila H, Pitkaniemi J, Tuomilehto J, Savolainen A, Alakulppi N, Tuomilehto-Wolf E, et al. HLA and susceptibility to juvenile idiopathic arthritis: a study of affected sibpairs in an isolated Finnish population. J Rheumatol 2004; 31: 2281-2285.

[38] Han H, Pyo CW, Yoo DS, Huh PW, Cho KS, Kim DS. Associations of Moyamoya patients with HLA class I and class II alleles in the Korean population. J Korean Med Sci 2003; 18: 876-880.

[39] Loewenthal R, Slomov Y, Gonzalez-Escribano MF, Goldberg I, Korostishevsky M, Brenner S, et al. Common ancestral origin of pemphigus vulgaris in Jews and Spaniards: a study using microsatellite markers. Tissue Antigens 2004; 63: 326-334.

[40] Amirzargar A, Mytilineos J, Farjadian S, Doroudchi M, Scherer S, Opelz G, et al. Human leukocyte antigen class II allele frequencies and haplotype association in Iranian normal population. Hum Immunol 2001; 62: 1234-1238.

[41] Chiewsilp P, Sujirachato K, Mongkolsuk T, Junpong S, Jootar S, Hathirat P. Preliminary study of HLA-ABCDR antigens in CML, ANLL, thalassemia and severe aplastic anemia in Thais. J Med Assoc Thai 2000; 83 Suppl 1: S130-136.

[42] Ng MH, Lau KM, Hawkins BR, Chik KW, Chan NP, Wong WS, et al. HLA-B67 may be a male-specific HLA marker of susceptibility to relapsed childhood ALL in Hong Kong Chinese and HLA-A33 or HLA-B17 signifies a higher presentation leukocytosis: A retrospective analysis on 53 transplant candidates (1989-2003). Ann Hematol 2006; 85: 535-541.

[43] Mainou-Fowler T, Dignum H, Taylor PR, Dickinson AM, Saunders PW, Proctor SJ, et al. Quantification improves the prognostic value of CD38 expression in B-cell chronic lymphocytic leukaemia. Br J Haematol 2002; 118: 755-761.

[44] Krober A, Seiler T, Benner A, Bullinger L, Bruckle E, Lichter P, et al. V(H) mutation status, CD38 expression level, genomic aberrations, and survival in chronic lymphocytic leukemia. Blood 2002; 100: 1410-1416. 
Table 1: HLA-A allele frequencies among Iranian CLL patients and healthy controls.

\begin{tabular}{|c|c|c|c|c|}
\hline Alleles & $\begin{array}{c}\text { CLL }(n=87) \\
(174 \text { alleles })\end{array}$ & $\begin{array}{c}\text { Healthy controls }(n=64) \\
(128 \text { alleles })\end{array}$ & Odds Ratio (95\% CI) & $P$ value \\
\hline A02:01 & $44(25.3)^{a}$ & $20(15.6)$ & $1.83(0.98-3.43)$ & 0.059 \\
\hline A24:01 & $29(16.7)$ & $21(16.4)$ & $1.02(0.53-1.97)$ & 0.92 \\
\hline A03:01 & $26(14.9)$ & $18(14.1)$ & $1.07(0.54-2.16)$ & 0.96 \\
\hline A11:01 & $21(12.1)$ & $5(3.9)$ & $3.38(1.16-10.55)$ & 0.02 \\
\hline A01:01 & $8(4.6)$ & $16(12.5)$ & $0.34(0.13-0.87)$ & 0.02 \\
\hline A32:01 & $8(4.6)$ & $7(5.5)$ & $0.83(0.27-2.63)$ & 0.93 \\
\hline A29:01 & $7(4)$ & $3(2.3)$ & $1.75(0.45-6.51)$ & 0.63 \\
\hline A30:01 & $7(4)$ & $5(3.9)$ & $1.03(0.33-3.17)$ & 0.8 \\
\hline A26:01 & $6(3.4)$ & $13(10.2)$ & $0.32(0.1-0.92)$ & 0.03 \\
\hline A33:01 & $5(2.9)$ & $8(6.3)$ & $0.44(0.12-1.54)$ & 0.25 \\
\hline A68:01 & $4(2.3)$ & $6(4.7)$ & $0.48(0.11-1.96)$ & 0.41 \\
\hline A23:01 & $2(1.1)$ & $5(3.9)$ & $0.29(0.04-1.69)$ & 0.23 \\
\hline A31:01 & $2(1.1)$ & 0 & 1.12 & 0.61 \\
\hline A66:01 & $2(1.1)$ & 0 & 1.12 & 0.61 \\
\hline A34:01 & $1(0.6)$ & 0 & $\mathrm{NI}$ & 0.87 \\
\hline A69:01 & $1(1.1)$ & 0 & NI & 0.87 \\
\hline A74:01 & $1(1.1)$ & 0 & NI & 0.87 \\
\hline A64:01 & 0 & $1(0.8)$ & 0 & 0.87 \\
\hline
\end{tabular}

${ }^{\mathrm{a}}$ The results represent the number $(\%)$ of the specified alleles expressed in the study groups, NI= not identified, $\mathrm{CI}=$ confidence interval (lower limit-upper limit). 
Table 2: HLA-B allele frequencies among Iranian CLL patients and healthy controls.

\begin{tabular}{|c|c|c|c|c|}
\hline Alleles & $\begin{array}{c}\text { CLL }(n=87) \\
(174 \text { alleles })\end{array}$ & $\begin{array}{c}\text { Healthy controls }(n=64) \\
(128 \text { alleles })\end{array}$ & Odds Ratio (95\% CI) & $P$ value \\
\hline B35:01 & $33(19)^{a}$ & $8(6.3)$ & $3.51(1.48-8.6)$ & 0.002 \\
\hline B51:01 & $17(9.8)$ & $14(10.9)$ & $0.88(0.39-1.98)$ & 0.88 \\
\hline B07:01 & $10(5.7)$ & $10(7.8)$ & $0.72(0.27-1.94)$ & 0.63 \\
\hline B13:01 & $9(5.2)$ & $7(5.5)$ & $0.94(0.31-2.9)$ & 0.88 \\
\hline B52:01 & $8(4.6)$ & $2(1.6)$ & $3.04(0.58-21.07)$ & 0.19 \\
\hline B18:01 & $7(4)$ & $1(0.8)$ & $5.15(0.64-41.34)$ & 0.14 \\
\hline B38:01 & $7(4)$ & $10(7.8)$ & $0.49(0.16-1.46)$ & 0.23 \\
\hline B08:01 & $6(3.4)$ & $7(5.5)$ & $0.62(0.18-2.11)$ & 0.57 \\
\hline B41:01 & $5(2.9)$ & $7(5.5)$ & $0.51(0.14-1.58)$ & 0.4 \\
\hline B62:01 & $5(2.9)$ & $2(1.6)$ & $1.86(0.36-9.33)$ & 0.71 \\
\hline B44:01 & $4(2.3)$ & $4(3.1)$ & $0.73(0.15-3.54)$ & 0.94 \\
\hline B50:01 & $4(2.3)$ & $2(1.6)$ & $1.48(0.27-7.91)$ & 0.97 \\
\hline B55:01 & $4(2.3)$ & $9(7)$ & $0.31(0.08-1.14)$ & 0.08 \\
\hline B27:01 & $3(1.7)$ & $1(0.8)$ & $2.23(0.23-20.97)$ & 0.84 \\
\hline B40:01 & $3(1.7)$ & $3(2.3)$ & $0.73(0.12-4.62)$ & 0.97 \\
\hline B49:01 & $2(1.1)$ & $4(3.1)$ & $0.36(0.05-2.33)$ & 0.42 \\
\hline B58:01 & $2(1.1)$ & $1(0.8)$ & $1.48(0.13-16.05)$ & 0.79 \\
\hline B63:01 & $2(1.1)$ & $3(2.3)$ & $0.48(0.08-2.89)$ & 0.72 \\
\hline B65:01 & $2(1.1)$ & $8(6.3)$ & $0.17(0.03-0.91)$ & 0.03 \\
\hline B15:01 & $1(0.6)$ & 0 & NI & 0.87 \\
\hline B37:01 & $1(0.6)$ & $1(0.8)$ & $0.73(0.05-11.65)$ & 0.61 \\
\hline B45:01 & $1(0.6)$ & $2(1.6)$ & $0.36(0.03-4.01)$ & 0.79 \\
\hline B53:01 & $1(0.6)$ & $17(13.3)$ & $0.04(0.01-0.32)$ & 0.00001 \\
\hline B57:01 & $1(0.6)$ & $3(2.3)$ & $0.24(0.03-2.33)$ & 0.2 \\
\hline B56:01 & 0 & $1(0.8)$ & 0 & 0.87 \\
\hline B72:01 & 0 & $1(0.8)$ & 0 & 0.87 \\
\hline
\end{tabular}

${ }^{\mathrm{a}}$ The results represent the number (\%) of the specified alleles expressed in the study groups, NI= not identified, $\mathrm{CI}=$ confidence interval (lower limit-upper limit). 
Table 3: HLA-A, B homozygote alleles frequency in CLL and controls.

\begin{tabular}{|c|c|c|c|c|}
\hline \multirow{2}{*}{ Alleles } & \multicolumn{2}{|c|}{ Homozygote alleles } & \multirow{2}{*}{$\begin{array}{c}\text { Odds Ratio } \\
\text { (95\% CI) }\end{array}$} & \multirow{2}{*}{$P$ value } \\
\hline & $\begin{array}{l}\text { CLL } \\
(n=87)\end{array}$ & $\begin{array}{c}\text { Healthy } \\
\text { controls }(n=64)\end{array}$ & & \\
\hline A24:01 & $5(8.5)^{a}$ & $2(3.1)$ & $\underline{1.89}(0.37-9.18)$ & 0.71 \\
\hline A02:01 & $3(3.5)$ & $1(1.6)$ & $\underline{\mathbf{2 . 2 2}}(0.23-20.5)$ & 0.85 \\
\hline B35:01 & $6(6.9)$ & 0 & $\mathrm{NI}$ & 0.08 \\
\hline B4005:01 & $2(2.3)$ & 0 & NI & 0.61 \\
\hline
\end{tabular}

${ }^{a}$ The results represent the number (\%) of the specified alleles expressed in the study groups, $\mathrm{NI}=$ not identified, $\mathrm{CI}=$ confidence interval (lower limit-upper limit). 
Table 4: HLA-A/B haplotype frequency in CLL patients and controls.

\begin{tabular}{|c|c|c|c|c|}
\hline Haplotypes & $\begin{array}{c}\text { HLA-A/B } \\
\text { haplotype } \\
\text { frequency in CLL } \\
\text { patients } \\
\end{array}$ & $\begin{array}{c}\text { HLA-A/B } \\
\text { haplotype } \\
\text { frequency in } \\
\text { controls } \\
\end{array}$ & Odds Ratio (95\% CI) & $P$ value \\
\hline A02:01/B35:01 & $10(5.7)^{a}$ & $3(2.3)$ & $2.54(0.69-8.73)$ & 0.25 \\
\hline A24:01/B35:01 & $10(5.7)$ & $2(1.6)$ & $3.84(0.82-16.5)$ & 0.12 \\
\hline A03:01/B35:01 & $10(5.7)$ & $2(1.6)$ & $3.84(0.82-16.5)$ & 0.12 \\
\hline A11:01/B35:01 & $8(4.6)$ & 0 & $\mathrm{NI}$ & 0.036 \\
\hline A02:01/B51:01 & $5(2.9)$ & $5(3.9)$ & $0.73(0.22-2.49)$ & 0.86 \\
\hline A32:01/B35:01 & $5(2.9)$ & $1(0.8)$ & $3.76(0.43-31.1)$ & 0.38 \\
\hline A02:01/B07:01 & $5(2.9)$ & 0 & $\mathrm{NI}$ & 0.14 \\
\hline A03:01/B51:01 & $4(2.3)$ & $5(3.9)$ & $0.58(0.16-2.15)$ & 0.64 \\
\hline A26:01/B51:01 & $4(2.3)$ & $2(1.6)$ & $1.48(0.27-7.91)$ & 0.97 \\
\hline A03:01/B18:01 & $4(2.3)$ & $1(0.8)$ & $2.99(0.33-26.02)$ & 0.97 \\
\hline A02:01/B41:01 & $3(1.7)$ & $3(2.3)$ & $0.73(0.15-3.59)$ & 0.97 \\
\hline A02:01/B38:01 & $3(1.7)$ & $3(2.3)$ & $0.73(0.15-3.59)$ & 0.97 \\
\hline A02:01/B13:01 & $3(1.7)$ & $3(2.3)$ & $1.11(0.19-6.51)$ & 0.73 \\
\hline A02:01/B18:01 & $3(1.7)$ & $1(0.8)$ & $2.23(0.23-20.97)$ & 0.84 \\
\hline A26:01/B07:01 & $3(1.7)$ & $1(0.8)$ & $2.23(0.23-20.97)$ & 0.84 \\
\hline A24:01/B62:01 & $3(1.7)$ & 0 & $\mathrm{NI}$ & 0.36 \\
\hline A02:01/B52:01 & $3(1.7)$ & 0 & $\mathrm{NI}$ & 0.36 \\
\hline A24:01/B52:01 & $3(1.7)$ & 0 & NI & 0.36 \\
\hline A24:01/B53:01 & $2(1.15)$ & $4(3.12)$ & $0.36(0.07-1.98)$ & 0.42 \\
\hline A24:01/B55:01 & $2(1.15)$ & $4(3.12)$ & $0.36(0.07-1.98)$ & 0.42 \\
\hline
\end{tabular}

${ }^{\text {a }}$ The results represent the number $(\%)$ of the specified alleles expressed in the study groups, NI= not identified, $\mathrm{CI}=$ confidence interval (lower limit-upper limit). Data for the most frequent haplotypes are presented in the table. 
Table 5: Comparison of HLA class I alleles frequencies in B-CLL patients from different ethnic populations

\begin{tabular}{|c|c|c|c|c|c|c|c|c|c|c|c|c|c|c|c|c|c|c|c|c|c|c|c|c|c|c|c|}
\hline \multirow[t]{2}{*}{ Country } & \multirow{2}{*}{$\begin{array}{c}\text { No. of } \\
\text { patients } \\
\text { (controls) }\end{array}$} & \multicolumn{25}{|c|}{ HLA-I alleles } & \multirow[b]{2}{*}{ Ref. } \\
\hline & & $\stackrel{\ddot{\theta}}{\ddot{\theta}}$ & 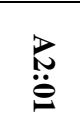 & 岂 & $\begin{array}{l}\vec{b} \\
\ddot{\theta}\end{array}$ & $\stackrel{\gtrless}{:}$ & $\underset{\ddot{\theta}}{\ddot{\theta}}$ & $\begin{array}{l}\text { 芯 } \\
\stackrel{0}{\Xi}\end{array}$ & $\begin{array}{l}\stackrel{d}{0} \\
\stackrel{0}{0}\end{array}$ & $\begin{array}{l}\stackrel{\vec{d}}{\mathscr{e}} \\
\stackrel{\ddot{\theta}}{\theta}\end{array}$ & $\begin{array}{l}\text { 客 } \\
\ddot{\theta}\end{array}$ & $\begin{array}{l}\text { ت্ّ } \\
\ddot{\theta}\end{array}$ & $\begin{array}{l}\text { ত্త } \\
\ddot{\theta}\end{array}$ & $\begin{array}{l}\ddot{\mathscr{o}} \\
\ddot{\theta}\end{array}$ & $\underset{\ddot{\omega}}{\ddot{\theta}}$ & 苛 & $\underset{\varpi \sigma}{\ddot{\sigma}}$ & $\begin{array}{l}\underset{N}{N} \\
\ddot{\theta}\end{array}$ & 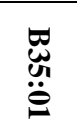 & $\begin{array}{l}\mathscr{\sigma} \\
\dot{t} \\
\ddot{\theta}\end{array}$ & 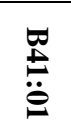 & $\underset{\mathscr{E}}{ \pm}$ & $\underset{\ddot{g}}{\stackrel{\mathscr{g}}{\ddot{\theta}}}$ & 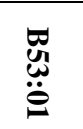 & $\begin{array}{l}\text { 嶵 } \\
\ddot{\theta}\end{array}$ & 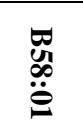 & \\
\hline Germany & $\begin{array}{c}101 \\
(157)^{*}\end{array}$ & $\begin{array}{c}24.8 \\
(31.9)\end{array}$ & $\begin{array}{r}59.4 \\
(48.4)\end{array}$ & NI & NI & $\mathrm{NI}$ & NI & NI & $\begin{array}{c}4 \\
(11.5)\end{array}$ & $\mathrm{NI}$ & NI & NI & NI & $\begin{array}{l}17.8 \\
(21.7)\end{array}$ & NI & NI & NI & NI & $\begin{array}{c}9.9 \\
(18.5)\end{array}$ & NI & NI & NI & NI & NI & NI & NI & 16 \\
\hline UK & $\begin{array}{c}85 \\
(600)\end{array}$ & $\begin{array}{c}34 \\
(36)\end{array}$ & $\begin{array}{c}55 \\
(48)\end{array}$ & $\begin{array}{c}19 \\
(24)\end{array}$ & $\begin{array}{c}19 \\
(17)\end{array}$ & $\begin{array}{c}7 \\
(9)\end{array}$ & $\begin{array}{c}15 \\
(12)\end{array}$ & NI & $\begin{array}{l}4 \\
(9)\end{array}$ & $\mathrm{NI}$ & NI & $\begin{array}{c}6 \\
(7)\end{array}$ & $\begin{array}{c}31 \\
(28)\end{array}$ & $\begin{array}{l}33 \\
(33)\end{array}$ & $\begin{array}{l}2 \\
\text { (3) }\end{array}$ & $\begin{array}{c}13 \\
(12)\end{array}$ & $\begin{array}{l}0 \\
(5)\end{array}$ & $\begin{array}{c}7 \\
(8)\end{array}$ & $\begin{array}{c}12 \\
(12)\end{array}$ & $\begin{array}{c}8 \\
(13)\end{array}$ & $\mathrm{NI}$ & NI & NI & NI & NI & NI & 33 \\
\hline$\underline{\text { USA }}$ & $\begin{array}{c}88 \\
(3761)\end{array}$ & $\begin{array}{c}32 \\
(30)\end{array}$ & $\begin{array}{c}56 \\
(50)\end{array}$ & $\begin{array}{c}27 \\
(30)\end{array}$ & $\begin{array}{l}23 \\
(20)\end{array}$ & $\begin{array}{c}8 \\
(10)\end{array}$ & $\begin{array}{c}7 \\
(10)\end{array}$ & $\begin{array}{c}10 \\
(10)\end{array}$ & NI & NI & NI & $\begin{array}{c}14 \\
(10)\end{array}$ & $\begin{array}{c}24 \\
(20)\end{array}$ & $\begin{array}{c}16 \\
(20)\end{array}$ & $\begin{array}{c}8 \\
(10)\end{array}$ & $\begin{array}{c}14 \\
(10)\end{array}$ & $\begin{array}{c}9 \\
(10)\end{array}$ & $\begin{array}{c}8 \\
(10)\end{array}$ & $\begin{array}{c}19 \\
(20)\end{array}$ & $\begin{array}{c}9 \\
(10)\end{array}$ & NI & NI & $\mathrm{NI}$ & NI & NI & NI & 21 \\
\hline UK & $\begin{array}{l}57 \\
(57)\end{array}$ & $\begin{array}{c}53 \\
(30)\end{array}$ & $\begin{array}{c}54 \\
(51)\end{array}$ & $\begin{array}{c}16 \\
(23)\end{array}$ & $\begin{array}{c}18 \\
(16)\end{array}$ & $\begin{array}{c}4 \\
(9)\end{array}$ & $\begin{array}{c}9 \\
(18)\end{array}$ & NI & $\begin{array}{c}7 \\
\text { (7) }\end{array}$ & NI & NI & $\begin{array}{c}11 \\
(16)\end{array}$ & $\begin{array}{c}30 \\
(30)\end{array}$ & $\begin{array}{c}44 \\
(19)\end{array}$ & $\begin{array}{c}5 \\
(5)\end{array}$ & $\begin{array}{l}12 \\
(5)\end{array}$ & $\begin{array}{l}7 \\
\text { (7) }\end{array}$ & $\begin{array}{l}4 \\
\text { (7) }\end{array}$ & $\begin{array}{c}5 \\
(11)\end{array}$ & $\begin{array}{l}11 \\
(9)\end{array}$ & $\begin{array}{c}0 \\
(2)\end{array}$ & NI & NI & $\begin{array}{c}2 \\
\text { (2) }\end{array}$ & NI & NI & 25 \\
\hline$\underline{\mathbf{U K}}$ & $\underline{\underline{(385})}$ & $\underline{\underline{30.1}} \underline{\underline{(36.7)}}$ & $\underline{62.7}$ & $\underline{\text { NI }}$ & $\underline{\text { NI }}$ & $\frac{\underline{10.8}}{\underline{(7.8)}}$ & $\underline{\text { NI }}$ & $\underline{\mathrm{NI}}$ & $\underline{\text { NI }}$ & $\underline{\text { NI }}$ & $\underline{\mathbf{N I}}$ & $\underline{\mathrm{NI}}$ & $\underline{\text { NI }}$ & $\underline{\underline{21.7}}$ & $\underline{\text { NI }}$ & $\underline{\mathrm{NI}}$ & $\underline{\text { NI }}$ & $\underline{\text { NI }}$ & $\underline{\text { NI }}$ & $\underline{\mathrm{NI}}$ & $\underline{\mathrm{NI}}$ & $\underline{\text { NI }}$ & $\underline{\text { NI }}$ & $\underline{\text { NI }}$ & $\underline{\text { NI }}$ & $\underline{\text { NI }}$ & $\underline{26}$ \\
\hline Germany & $\begin{array}{c}79 \\
(329)\end{array}$ & $\begin{array}{c}20.3 \\
(30.4)\end{array}$ & $\begin{array}{l}60.8 \\
(45.9)\end{array}$ & NI & NI & $\mathrm{NI}$ & NI & $\mathrm{NI}$ & NI & NI & NI & NI & NI & $\begin{array}{c}16.5 \\
(22.2)\end{array}$ & NI & NI & $\begin{array}{c}11.4 \\
(10.3)\end{array}$ & NI & $\begin{array}{c}10.1 \\
(15.5)\end{array}$ & NI & NI & NI & NI & NI & NI & NI & 22 \\
\hline IRAN & $\begin{array}{c}87 \\
(64)\end{array}$ & $\begin{array}{c}4.6 \\
(12.5)\end{array}$ & $\begin{array}{c}25.3 \\
(15.6)\end{array}$ & $\begin{array}{c}14.9 \\
(14.1)\end{array}$ & NI & NI & $\begin{array}{l}12.1 \\
(3.9)\end{array}$ & $\begin{array}{c}4 \\
(2.3)\end{array}$ & NI & $\begin{array}{c}4 \\
(3.9)\end{array}$ & $\begin{array}{c}2.3 \\
(4.7)\end{array}$ & NI & $\begin{array}{c}5.7 \\
(7.8)\end{array}$ & NI & $\begin{array}{c}5.2 \\
(5.5)\end{array}$ & $\mathrm{NI}$ & $\begin{array}{c}4 \\
(0.8)\end{array}$ & $\begin{array}{c}1.7 \\
(0.8)\end{array}$ & $\begin{array}{c}19 \\
(6.3)\end{array}$ & $\begin{array}{c}1.7 \\
(2.3)\end{array}$ & $\begin{array}{c}2.9 \\
(5.5)\end{array}$ & $\begin{array}{c}2.3 \\
(3.1)\end{array}$ & $\begin{array}{c}9.8 \\
(10.9)\end{array}$ & $\begin{array}{c}0.6 \\
(13.3)\end{array}$ & $\begin{array}{l}2.3 \\
(7)\end{array}$ & $\begin{array}{c}1.1 \\
(0.8)\end{array}$ & $\begin{array}{c}\text { Present } \\
\text { study }\end{array}$ \\
\hline
\end{tabular}

"Data represent the percentage of alleles in CLL (normal controls), NI= not identified 